\title{
What more evidence is needed? Remove menthol cigarettes from the marketplace-now
}

\author{
Valerie Yerger (D) 1,2
}

Tobacco remains the leading cause of preventable death and disease in the USA and many other countries. However, among all racial and ethnic groups in the USA, African Americans bear the greatest burden from tobacco-related morbidity and mortality. ${ }^{1}$ Every year, 45000 African Americans prematurely and unnecessarily die from tobacco-caused diseases. An estimated $85 \%$ of them smoked menthol cigarettes. $^{2}$

Menthol's sensory properties reinforce smoking, increase uptake of nicotine and toxic smoke components, and discourage cessation. Menthol's cooling, anaesthetic and analgesic effects ease initiation among new smokers by masking the harshness and irritation of tobacco smoke, reducing pain sensations in the mouth and throat, and enabling deeper inhalation that facilitates greater exposure to nicotine. ${ }^{3}$

On 3 March 2009, Representative Henry Waxman and 124 congressional cosponsors introduced H.R. 1256-the 'Family Smoking Prevention and Tobacco Control Act.'4 Representative Waxman's Committee Report expressed concerns about the disproportionate use of menthol cigarettes among African Americans, the targeted marketing of menthol cigarettes in black communities, and the higher rates of lung cancer among African American smokers compared with non-African American smokers, urging the Secretary of Health and Human Services to move quickly to address the unique public health issues posed by menthol cigarettes. Yet, although most other characterising flavours in cigarettes were prohibited in 2009 under the final version of the Family Smoking Prevention and Tobacco Control Act, menthol was inexplicably excluded. ${ }^{5}$ It has been estimated that hundreds of thousands of African Americans and other menthol smokers are destined to die

${ }^{1}$ Social and Behavioral Sciences, University of California San Francisco, San Francisco, California, USA

${ }^{2}$ African American Tobacco Control Leadership Council, San Francisco, California, USA

Correspondence to Dr Valerie Yerger, Social and Behavioral Sciences, University of California San Francisco, San Francisco, California 94143-0612, USA; Valerie.Yerger@ucsf.edu prematurely if the exemption of menthol is allowed to continue. ${ }^{6}$

The disproportionate toll of menthol cigarettes among African Americans compared with the general population is a social injustice. The black community has long been subjected to the predatory marketing of mentholated tobacco products, particularly in lower income areas, where there are not only more advertisements, but more promotions and cheaper prices for menthol cigarettes when compared with more affluent neighbourhoods. ${ }^{7}$ Tobacco companies also heavily rely on their cooptation of community leaders to defuse tobacco control efforts. ${ }^{8}$ Black-led organisations with financial ties to the tobacco industry have played a critical role in disseminating misinformation throughout the black community. Such misinformation, for example, includes the idea that local policies prohibiting the sale of mentholated tobacco products are racist and will increase the criminalisation of individuals who possess or smoke them, exploiting legitimate concerns about racist policing to defend the tobacco industry's targeted predation on the black community. ${ }^{9} 10$

Authors Mendez and Le, in their article 'Consequences of a match made in hell: the harm caused by menthol smoking to the African American population over 1980-2018,'11 show why none of us can remain silent and complicit. This paper should serve as a kick upside the head for those who are in a position to remove these deadly products from the marketplace. Until this paper, no prior study has fully quantified the health harm inflicted on African Americans by menthol cigarettes. Yet, for at least three decades, African American tobacco control activists have been out there resisting the pervasive presence of the tobacco industry and their deadly products in black communities, ${ }^{12-15}$ including filing a lawsuit to get the Center for Tobacco Products of the US Food and Drug Administration (FDA) to act on menthol. ${ }^{16}$ Now the evidence is irrefutable: menthol cigarettes are killing our people at a rate unmatched by any other assaults on our community.

Though constituting only $12 \%$ of the total US population, African Americans bear an alarming amount of the total menthol-related harm: $41 \%$ of the smoking-related premature deaths and $50 \%$ of the life-years lost. This analysis demonstrates the contribution of menthol cigarettes toward the annihilation of a people already under siege by a racist society and its myriad of inequities, governmental policies and political domination. ${ }^{17}$ Institutionalised racism, its long historical impact, and the associated, yet unresolved, intergenerational trauma experienced by black people in America have made them vulnerable to the clever marketing and predatory dumping of mentholated tobacco products in their communities.

For decades, the tobacco industry has exploited social and economic inequities to foster the uptake and use of menthol cigarettes, and create brand loyalty among African Americans. Tobacco companies strategically targeted menthol cigarettes to low-income African Americans, blanketing inner city communities with marketing, free samples, and music promotions, ${ }^{19}$ and thereby contributing to the tobacco-related health disparities observed today, as Mendez and Le have now confirmed. We can no longer ignore the intersecting, overlapping and distinctive systems of oppression that shape 'being black in America' and how menthol cigarettes contribute to sustained and widening health disparities. ${ }^{20}$

This paper is compelling on its own merit; however, read in tandem with the authors' previous paper, ${ }^{21}$ one can fully appreciate the significant role menthol cigarettes have played in addicting millions of young people to nicotine and in the deaths of thousands due to tobacco. As the authors emphasise, mentholated cigarettes have a 'significant detrimental impact on the public's health and could continue to pose a substantial health risk.'

More than a decade after the FDA was given authority to regulate tobacco products, long after other flavours favoured by white children were banned from most tobacco products, and long after the first of several scientific reports found menthol cigarettes to pose a public health risk above that seen with non-menthol cigarettes, ${ }^{22-24}$ the FDA still has not acted. The black community has been abandoned at the federal level, leaving activists to seek local and state policy changes. So, the question for me is: Given the mountains of evidence, will anything push the federal government to consider social justice and act on its commitment to finally ban menthol cigarettes and all flavoured cigars? ${ }^{25} 26$

The recent highly publicised killings of black men and women, including George Floyd, Ahmaud Arbery, Breonna Taylor and many others, brought to the forefront 
of our nation's conscience how pervasively racism permeates everyday life. Whether one is on the receiving or perpetuating end of racist behaviours or if one benefits from or is negatively impacted by racist policies, we all recently watched how quickly the world mobilised to support the Black Lives Matter movement. Are we in a moment to leverage this movement?

If menthol cigarettes are allowed to stay in the marketplace, the lives of African Americans and others remain at increased risk. Conversely, removing these terrible products will benefit not only the black community but also other racial and ethnic groups, the lesbian, gay, bisexual and transgender community, youth and those with behavioural health issues, since these groups also disproportionately smoke mentholated cigarettes over non-mentholated cigarettes. ${ }^{27-30} \mathrm{I}$ ask that others stand with us to repair a wrong done to the black community, as we stand with you. There is simply no ethically acceptable reason to allow the tobacco industry to continue using a flavouring that makes it easier to start smoking and harder to quit. Whether we work at the federal, state or local level, we are empowered in our collective work to protect our communities from our number one killer, a corporate industry of federally adjudicated racketeers. ${ }^{31}$ This paper provides us with added ammunition to get that vital work done. It is long past time for the FDA to get inoculated against whatever the hell is keeping it from getting these deadly products out of the marketplace.

Contributors As the sole author, VY, I made substantial contributions to the conception and design of the work. I drafted the work and revised it critically for important intellectual content. As the sole author, I provided final approval of the version published and am accountable for all aspects of the work in ensuring that questions related to the accuracy or integrity of the work are appropriately investigated and resolved.

Funding The authors have not declared a specific grant for this research from any funding agency in the public, commercial or not-for-profit sectors.

Competing interests None declared.

Patient consent for publication Not applicable.

Provenance and peer review Commissioned; internally peer reviewed.

(C) Author(s) (or their employer(s)) 2021. No commercial re-use. See rights and permissions. Published by BMJ.

\section{Check for updates}

To cite Yerger V. Tob Contro/ Epub ahead of print: [please include Day Month Year]. doi:10.1136/ tobaccocontrol-2021-056988

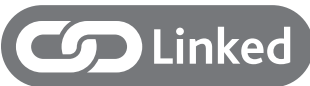

- http://dx.doi.org/10.1136/tobaccocontrol-2021056748
Tob Control 2021;0:1-2.

doi:10.1136/tobaccocontrol-2021-056988

\section{ORCID iD}

Valerie Yerger http://orcid.org/0000-0003-2469-402X

\section{REFERENCES}

1 Centers for Disease Control and Prevention, Tobacco use among U.S. racial/ ethnic minority groups. A report of the surgeon General. Washington, DC, 1998. https:// www.cdc.gov/tobacco/data_statistics/sgr/1998/ complete_report/

2 Villanti AC, Mowery PD, Delnevo CD, et al. Changes in the prevalence and correlates of menthol cigarette use in the USA, 2004-2014. Tob Control 2016;25:ii14-20.

3 Kreslake JM, Wayne GF, Alpert HR, et al. Tobacco industry control of menthol in cigarettes and targeting of adolescents and young adults. Am J Public Health 2008:98:1685-92.

4 Family Smoking Prevention and Tobacco Control Act P.L. 111e31, 2009. Available: https://www.govinfo. gov/content/pkg/PLAW-111 publ31/pdf/PLAW$111 \mathrm{publ31.pdf}$

5 Family Smoking Prevention and Tobacco Control Act 21, 2009. Available: https://www.fda.gov/ tobacco-products/rules-regulations-and-guidance/ family-smoking-prevention-and-tobacco-control-actoverview\#: :text=To\%20protect $\% 20$ the $\% 20$ public $\%$ 20 and, and $\% 20$ marketing $\% 20$ of $\% 20$ tobacco $\%$ 20products. [Accessed 22 Jun 2009].

6 Levy DT, Pearson JL, Villanti AC, et al. Modeling the future effects of a menthol ban on smoking prevalence and smoking-attributable deaths in the United States. Am J Public Health 2011;101:1236-40.

7 Henriksen L, Schleicher NC, Dauphinee AL, et al. Targeted advertising, promotion, and price for menthol cigarettes in California high school neighborhoods. Nicotine Tob Res 2012;14:116-21.

8 Yerger VB, Malone RE. African American leadership groups: smoking with the enemy. Tob Control 2002:11:336-45.

9 Tulloss KW. Community leaders come together against racism and discrimination protesting senate bill 793 Available: https://lasentinel.net/community-leaderscome-together-against-racism-and-discriminationprotesting-senate-bill-793.html [Accessed 20 Aug 2020].

10 Brown SM. Conference expresses opposition to proposed Maryland menthol ban. Washington Informer Newspaper. Available: https://www. washingtoninformer.com/baltimore-black-baptistministers-conference-expresses-opposition-toproposed-maryland-menthol-ban/ [Accessed 11 Feb 2021].

11 Mendez D, TT Le. Consequences of a match made in hell: the harm caused by menthol smoking to the African American population over 1980-2018. Tob Control 2021. doi:10.1136/\%20 tobaccocontrol-2021-056748

12 African American Tobacco Control Leadership Council. What's menthol got to do with it? Everything! (Still): the plight of African Americans and mentholated tobacco products. Washington, D.C: International Press Briefing, National Press Club, 2019. https://youtu.be/ 7wT9Lbn8nmk

13 Sixfootah the Poet. What menthol cigarettes have taken from me. San Francisco Bayview national black newspaper. Available: https://sfbayview.com/2020/ 04/what-menthol-cigarettes-have-taken-from-me/ [Accessed 05 Apr 2020].

14 RJ Reynolds new "uptown" targets Blacks, 1990. Advocacy Institute. Available: https://www. industrydocuments.ucsf.edu/docs/mkvw0005 [Accessed 04 Sep 2021].
15 Sutton CD, Robinson RG. The marketing of menthol cigarettes in the United States: populations, messages, and channels. Nicotine Tob Res 2004;6 Suppl 1:83-91.

16 African American Tobacco Control Leadership Council v. US Department of Health and Human Services, Case No. 4:20-cv-4012-KAW (N.D. Cal.), 2021. Available: https://www.publichealthlawcenter.org/sites/default/ files/AATCLC-v-FDA-Defs-Second-Motion-to-Dismiss. pdf

17 Alexander M. The new Jim Crow: mass incarceration in the age of colorblindness. New York, NY: The New Press, 2012.

18 Dawes D. The political determinants of health. Baltimore, MD: Johns Hopkins University, 2020

19 Yerger VB, Przewoznik J, Malone RE. Racialized geography, corporate activity, and health disparities: tobacco industry targeting of inner cities. $J$ Health Care Poor Underserved 2007; 18:10-38.

20 Kong AY, Golden SD, Berger MT. An intersectional approach to the menthol cigarette problem: what's race(ism) got to do with it? Crit Public Health 2019;29:616-23.

21 Le TT, Mendez D. An estimation of the harm of menthol cigarettes in the United States from 1980 to 2018. Tob Control 2021. doi:10.1136/ tobaccocontrol-2020-056256. [Epub ahead of print: 25 Feb 2021].

22 Tobacco Products Scientific Advisory Committee, US Food and Drug Administration. Menthol cigarettes and public health: review of the scientific evidence and recommendations, 2011. Available: https://wayback. archive-it.org/7993/20170405201731/https://www. fda.gov/downloads/AdvisoryCommittees/Committe esMeetingMaterials/TobaccoProductsScientificAdv isoryCommittee/UCM269697.pdf [Accessed 04 Sep 2021].

23 US Food and Drug Administration. Preliminary scientific evaluation of the possible public health effects of menthol versus nonmenthol cigarettes. Silver Spring, MD: Center for Tobacco Products, Food and Drug Administration, 2013.

24 Tobacco Control Legal Consortium et al. Citizen Petition to the US Food and Drug Administration, Prohibit menthol as a characterizing flavor in cigarettes, 2013. Available: https://www.publiche althlawcenter.org/sites/default/files/resources/tclcfdacitizenpetition-menthol-2013.pdf

25 FDA commits to evidence-based actions aimed at saving lives and preventing future generations of smokers, 2021. Available: https://www.fda.gov/newsevents/press-announcements/fda-commits-evidencebased-actions-aimed-saving-lives-and-preventingfuture-generations-smokers [Accessed 29 Apr 2021]

26 Statement by HHS Secretary Xavier Becerra on FDA tobacco actions on menthol cigarettes and flavored cigars, 2021. Available: https://www.hhs.gov/about/ news/2021/04/29/statement-hhs-secretary-xavierbecerra-fda-tobacco-actions-menthol-cigarettesflavored-cigars.html [Accessed 29 Apr 2021].

27 Mukherjea A, Wackowski OA, Lee YO, et al. Asian American, Native Hawaiian and Pacific Islander tobacco use patterns. Am J Health Behav 2014;38:362-9.

28 Delnevo CD, Villanti AC, Giovino GA. Trends in mentho and non-menthol cigarette consumption in the U.S.A.: 2000-2011. Tob Control 2014;23:e154-5.

29 Fallin A, Goodin AJ, King BA. Menthol cigarette smoking among lesbian, gay, bisexual, and transgender adults. Am J Prev Med 2015;48:93-7.

30 Young-Wolff KC, Hickman NJ, Kim R, et al. Correlates and prevalence of menthol cigarette use among adults with serious mental illness. Nicotine Tob Res 2015;17:285-91.

31 Eubanks SY, Glantz SA. Bad acts: the racketeering case against the tobacco industry. Washington, DC: American Public Health Association, 2013. 